\title{
Fulfilling the Mission of the Church in Ghana in the 21st Century: Lessons from India in the 16th and 17th Centuries
}

Seth Asare - Danso'

${ }^{1}$ Department of Arts Education, University of Cape Coast, Ghana.

\begin{abstract}
This historical study examines the spread of Christianity in India in the 16th and 17th centuries, and lessons to be drawn by Christian churches in Ghana in the 21st century. Personal interview and content analysis of primary and secondary source documents were used for data collection. The grounded theory design was used to develop four theories, namely: "cultural rejection approach", "cultural replacement approach", "cultural sharing approach" and "cultural transformation approach" to mission. The research findings revealed that Christianity was introduced in India to liberate the people from ignorance. The Jesuit understood the motives of mission to be cross-cultural, international, co-operative and holistic in nature. It further revealed that the Jesuit used the "cultural transformation approach" to mission, which required the use of "radical identification", "culture transfer", "indigenization", "inculturation" and "primal religion" as evangelistic methods to fulfil the mission mandate. The study recommended that churches in Ghana adapt the "cultural transformation approach" to mission to suit their cultural environments, so that the use of "radical identification" and "culture transfer" will reduce inequality, in fulfilment of UN SDG 10; while the use of "indigenization", "inculturation" and "primal religion" will provide inclusive and equitable quality (theological) education, in fulfilment of UN SDG 4.
\end{abstract}

\section{Correspondence:}

Seth Asare-Danso

Email: sasare-danso@ucc.edu. gh

\section{Manuscript}

Received 15th June 2020,

Accepted 5th August 2020,

Published online 10th August 2020.

Keywords: Church, Mission, Jesuit, Indigenization, Inculturation, Primal Religion

C 2020 The Authors. Published and Maintained by Noyam Publishers.

This is an open access article under the CCBY license (http://creativecommons.org/licenses/by/4.0/).

\section{INTRODUCTION}

In this historical study, the author examines the concepts "church" and "mission". This was followed by a discussion on theological responses to mission, and an examination of four theological approaches to mission, namely: "cultural rejection approach", "cultural replacement approach", "cultural sharing approach" and "cultural transformation approach". Furthermore, the study examines how an Italian Jesuit used the "cultural transformation approach" to mission to introduce Christianity in India in the $16^{\text {th }}$ and $17^{\text {th }}$ centuries, using "radical identification", "cultural transfer", "indigenization", "inculturation" and "primal religion" as his evangelistic strategies. Finally, the study discusses the lessons that $21^{\text {st }}$ century Christian churches in Ghana could learn from Jesuit Christianity in India in the $16^{\text {th }}$ and $17^{\text {th }}$ centuries.

\section{The Concept of Church}

In Christian Theology, the concept of "church" is studied under the branch of theology which is referred to as "ecclesiology". "Ecclesiology" is the study of the Christian church, comprising its origin, its relationship with Jesus Christ, its role in salvation, its polity or governance structure, and its leadership. The term "church" is coined from the

\footnotetext{
This paper was presented as part of the 10th Archbishop Le Maire Memorial lectures instituted by the St. Nicholas Anglican Seminary at Cape Coast, where the author was the Keynote Speaker in November 2018. It was developed from a PhD course entitled "World Christian History", which was taken by the author and taught by Prof. Emeritus Andrew F. Walls at Akrofi Christaller Institute for Mission, Research and Theology, Akropong-Akuapem in 2005
} 
Greek word "ekklesia", which literally means "to call out". ${ }^{2}$ The "church" therefore refers to people who have been called out for a purpose, i.e., to fulfil a mission. The concept "church" was first used in a Christian sense in Acts 5:11.

The Church is a community of believers who have been called out to be an example to the world. ${ }^{3}$ According to Albert Pete Pero, a professor emeritus of systematic theology at the Lutheran School of Theology, Chicago, the church is "the body of believers who respond positively in faith to the call of God in Christ to serve not only God but all humanity. The church exists then where the people hear the Word, gather around sacraments, and do the work of salvation; where the Lordship of Christ reigns and where people take responsibility for God's world." 4

The church is made up of children, youth, adults, men and women, males and females. Therefore, any assembly of God's people that discriminate against others, by virtue of their sex, race, colour, ethnicity or social status cannot adequately be described as a church. The church, which is the body of Christ, finds it fulfilment in carrying out the mission of Christ.

Jesus Christ had a mission to fulfil, and the church which he founded must have the same mission. Jesus Christ expressed his own theology of mission through the declaration which he made in Luke 4:18-20, that He had been anointed by the spirit to preach good news to the poor, proclaim freedom for prisoners, bring recovery of sight to the blind, release the oppressed, and to proclaim the acceptable year of the Lord. The church therefore exists to carry out a mandate, i.e., to fulfil the mission of Jesus Christ, to establishing the Kingdom of God. This gives the church its focus and makes it mission-oriented. The next section examines the concept of mission.

\section{The Concept of Mission}

According to David Bosch, the South African missiologist, the work of "mission" requires that a person or group of persons are sent to a particular destination to perform a task or an assignment. ${ }^{5}$ From the definition, two parties are involved in mission. These are the "Sender" and the "One who has been sent". For the one to be sent to respond positively to the Sender, he or she must understand the "goal" of mission. Secondly, the one who has been sent must develop certain "motives" that will help him or her to fulfil the mission. Finally, the one who has been sent should develop certain "methods" to help him or her to achieve the goal. This must therefore help in defining theology of mission.

Gerald Anderson defined "theology of mission" as "concerned with the basic presuppositions and underlying principles which determine, from the standpoint of Christian faith, the motives, strategy and goals of the Christian world mission." ${ }^{\prime \prime}$ It is therefore important that the goal of mission is examined.

Mission must be understood as a calling from God to liberate His people from oppression, hardship, ignorance and poverty, among others. This is what Idowu believed about the Church:

... to be effective in her life and mission, she (Church) must respect, preserve and dedicate to the glory of God anything that is of value in the culture and institutions of the country. The purpose of Christianity, she must constantly remember, is to fulfil, and not to destroy; to make free, and not to enslave. ${ }^{?}$

Therefore, for the church to engage in mission, it is required to work towards the liberation of people from poverty, ignorance and hardship. Mission has its foundation on scripture. The Old Testament provides a theological foundation of mission when God used Moses to deliver the Israelites from bondage under the leadership of Moses (Exodus 6). God's love motivated him to call Moses to deliver the Israelites from captivity. The initiative came from God. As a result, God is seen to be the originator of mission. Therefore, all those who give positive response to the Word of God and are "called out" carry out the mission of God. It is for this reason that the Church of God should be missionoriented. The church should not add to the burden of people.

Similarly, from the New Testament perspective, God's mission was executed when Jesus Christ responded to God's call to fulfil His mission on earth, as quoted by the Prophet Isaiah,

Then I heard a voice of the Lord saying "Whom shall I send? And who will go for us?" And I said,

"Here am I, send me!" (Isaiah 6:8).

Again, in the New Testament, during Jesus Christ's post-resurrection ministry, he gave the disciples the Great Commission, which was a divine mandate, to

"Go and make disciples of all nations, baptising them in the name of the Father,

Son and Holy Spirit...." (Matthew 28:19).

\footnotetext{
K. Shekhar, The Concept of the Church in Christianity. Imperial Journal of Interdisciplinary Research (IJIR), 3, no 2, (2017). http://www.onlinejournal.in

David N. A. Kpobi, Mission in Ghana: The Ecumenical Heritage. (Accra: Asempa Publishers, 2008), 7.

Albert Pete Pero, “A view of Lutheran Unity from a Black Perspective”, in Dialogue, 20, (1981), 161.

David Bosch, Transforming Mission. (New York: Orbis Books, 1991), 1.

Neil Stephen, Gerald H. Anderson \& John Goodwin, eds. A Concise Dictionary of the World Mission. (London: Lutterworth Press, 1971$)$, 594.

E. B. Idowu, Towards an Indigenous Church. (London: Oxford University Press, 1965), 7.
} 
It was against this background, that the Basel Evangelical Mission Society (popularly known as the Basel Mission) which established the Presbyterian Church of Ghana in 1828 saw mission as a calling from God to fulfil the mission of Jesus Christ, which was the Great Commission in Matthew 28:19, as quoted above. In response to God's divine mandate (i.e. The Great Commission), the first batch of the Basel Missionaries responded to the call to mission in $1828 .{ }^{8}$ Their positive response to mission led to the establishment of the Basel Mission Church which has now become the Presbyterian Church of Ghana.

The biblical foundation of mission must challenge people to consider the kind of motives that they have for embarking on mission. Terry C. Hulbert suggested four motives, which he thought could be helpful guide in mission. These were: cross-cultural, international, co-operative and holistic. ${ }^{9}$ Hubert believed that mission should be crosscultural, meaning it must cut across different cultures. He also believed that mission should have international dimension by going beyond the borders of countries. Thirdly, mission should require a co-operative effort of all, rather than becoming an individual affair. Finally, he proposed that mission should be holistic by addressing not only the spiritual needs but also the economic, socio-cultural and emotional needs of people.

\section{Early Christian Mission in India before the $16^{\text {th }}$ Century}

According to India Country Profile (2020), ${ }^{10}$ India has a population of 1.3 billion. Its capital is New Delhi. In terms of religious population, Hinduism is the first religion with the largest population in India, followed by Islam. Christianity is the third religion with the largest population, followed by Sikhism and Buddhism. Tradition and legends have revealed that the first Christians in India were converted by St. Thomas, one of the twelve apostles of Jesus Christ in the year $52 \mathrm{AD}$. It is believed that St. Thomas established seven churches on the south-western coast of Malabar in India. ${ }^{11} \mathrm{He}$ then appointed elders in each of the seven churches from Brahmin families. St. Thomas then went to the eastern coast to plant a few churches there. Even though the historicity of the St. Thomas tradition has been disputed due to lack of contemporary evidences, there seem to be some element of truth in it. It has been documented that Christianity in India was represented by John, "Bishop of Persia and Great India" at the Council of Nicaea, which was held in 325 AD, and that this Bishop was one of the signatories at the Council of Nicea in the Acts of the Apostles". ${ }^{12}$

Prof. Andrew Walls, the British Church historian, believed that the Church in India had a historical connection with the Syrian Church, which had its headquarters in Antioch. He added that this might have caused the migration of three to four hundred Christian families from Mesopotamia to the south-western coast, under the leadership of Thomas of Cana in $345 \mathrm{AD}$. This was followed by a second migration of Christians in 833 AD. ${ }^{13}$ Even though Christianity was introduced in India long ago, it was not deeply rooted for centuries. It remained as a dominant church with lack of dynamism to impact non-Christians.

\section{Christian Mission in India in the $16^{\text {th }}$ and $17^{\text {th }}$ Centuries}

According to Prof. Andrew Walls, the arrival of the Portuguese in the $16^{\text {th }}$ century, followed by Vasco de Gama's successful voyage to India in 1498 changed the face of the history of Christianity in India. ${ }^{14}$ The Portuguese monopolised European trading in the $16^{\text {th }}$ century. Later on, other European nations like the Dutch, the Danes, the English and the French entered the scene to compete with the Portuguese. However, it was the Portuguese who were mission-minded and for that matter were able to do notable mission work under a system known as the "Padroado". ${ }^{15}$

Before the Padroado, the Pope (Pope Alexander VI) had published a bull, "Inter caetera" to divide the New World between Spain and Portugal in 1493, using the Papal Line of Demarcation. Spain won control of lands discovered west of the line, while Portugal gained rights to new lands to the east of the line. ${ }^{16}$

"Padroado" was a system that was entrusted to the Portuguese kings by the Pope to evangelize the indigenous people within the Portuguese territories where they had set up their trading colonies. The Spaniard kings were also given the same privilege. The "Padroado" system gave kings the right to send bishops, priests and missionaries to foreign lands to evangelize. ${ }^{17}$

\footnotetext{
8 Seth Asare-Danso, "Building a Mission-Oriented Church in Ghana in the 21 st century: The Role of Theological Education". ERATS, 6, no 3, (June, 2020), 190-199. DOI: https://doi.org/10.38159/erats.2020065

9 Terry C. Hulbert, World Missions Today. (Wheaton, Illinois: Evangelical Teacher Training Association, 1981).

10 India Country Profile https://www.bbc.com Accessed February 18, 2020.

11 Earl E. Cairns, Christianity through the centuries. (Grand Rapids: Zondervan, 1996).

12 Fr. J. C. Hrangkhuma, The Church in India, in Church in Asia Today, ed. Saphir Athyal. (Singapore: Lousanne Committee for World Evangelization, 1996), 393-400.

13 Andrew F. Walls, The Cross-Cultural Process in Christian History: Studies in the Transmission and Appropriation of Faith. (Maryknoll, New York: Orbis Books, 2005)

14 Ibid.

15 Ibid.

$16 \mathrm{https} / / \mathrm{www}$. britannica.com>event, accessed October 20, 2018.

7 Walls, The Cross-Cultural Process in Christian History.
} 
In line with the system of "Padroado", King John III of Portugal sent Rev. Fr. Francis Xavier (1506-1552), who was a Roman Catholic Priest and a Jesuit, to spread Christianity in the Portuguese territories in India in 1541. Following his pioneering work in India, another Roman Catholic Priest and a Jesuit was sent by Pope Paul V to go to India and evangelize. His name was Rev. Fr. Roberto de Nobili.

Rev. Fr. Roberto de Nobili (1577-1656) was born into a wealthy family that had great influence on the community. He decided to join the Jesuits (The Society of Jesus). He studied Logic, Science, Astronomy, Metaphysics, Psychology and Ethics. From the content of his own letter which was addressed to Pope Paul V, Jesuit Father Roberto de Nobilis left Rome in 1603 to go to India to evangelize. ${ }^{18}$ After spending two years travelling, he arrived at Goa, and continued to Cochin and finally arrived at Madurai on $15^{\text {th }}$ November 1606 to begin a fifty-year career in the Jesuit Madurai Mission. ${ }^{19}$

When Rev. Fr. Roberto de Nobili went to Madurai, other Jesuits had been working there for eleven (11) years. However, he observed that all the people that his colleagues converted were either fishermen from the coast or Portuguese. Not even a single convert was a native of Madurai. Fr. Roberto de Nobili decided to adopt certain measures and use certain strategies that will enable him to do effective evangelism among the indigenous people. The methods he used included radical identification, cultural transfer, indigenization and inculturation, among others. ${ }^{20}$ The Jesuit also made use of the primal religion of the indigenous people and developed it as a basis for the propagation of the gospel. ${ }^{21}$ By the time of his death in 1656 at the age of 79 years, he had succeeded in doing the work of mission in India and had won more souls for Jesus Christ to the admiration of all. Today, if the religious profile of India reveals that Christianity runs third after Hinduism and Islam, it is partly due to the pioneering work of Rev. Fr. Roberto de Nobili. It will be very important to learn about the Jesuit Order.

\section{The Jesuit Order}

The Jesuits is a religious order in the Roman Catholic Church. Sir Ignatius Loyola (1491-1556) and six (6) of his fellow students from the university of Paris, France founded the Jesuit Order in 1534 but Pope Paul III formally approved of it in 1540. Ignatius Loyola was born into an aristocratic Basque family near Azpeitia, Spain. His real name was Inigo de Loyola. He was a courtier of the Duke of Najera. He fought the French at Pamplona in 1521 during which he was severely wounded. It was during the time of his recuperation that he read stories about the life of Jesus Christ and about the saints. The books convinced him to abandon his ambitions and pleasures that he was seeking in life. ${ }^{22}$

He went to the Benedictine Monastery near Barcelona. Between the years 1522 and 1523, Ignatius Loyola lived in a cave and subjected himself to many physical discomforts. He later prepared himself for the priesthood by studying theology and the humanities at the University of Paris, France from 1528 to 1535. It was during this period (1534) that Ignatius Loyola and six other colleagues formed the Society of Jesus (SJ) or the Jesuit Order. ${ }^{23}$

An oral interview ${ }^{24}$ conducted by the author revealed that the Jesuit Order was formed with the following objectives:

1. To propagate the gospel or to evangelise;

2. To defend the Christian faith; and

3. To deepen people's knowledge in Christianity.

The informant revealed that its membership was restricted to males. Members who were admitted into the order were made to undergo a two-year spiritual training, after which they take the oath of celibacy, poverty and obedience to superiors. They then go through an academic training for a period of about fifteen (15) years.

According to Rev. Fr. Donald Hinfey, a Jesuit, who happened to be the informant, the Jesuit Order has four groups of members, namely:

1. Scholastics (younger men in priesthood for the ministry),

2. Temporal coadjutors (brothers),

3. Spiritual coadjutors, and

4. The solemnly professed.

The scholastics and the brothers are not ordained into the priesthood. They need to graduate into the spiritual coadjutors

\footnotetext{
Robert de Nobili, "A Letter of Father Robert de Nobili to the Pope”, in Indian Church History Review, 2, (1968), 84-96, cited in Aspects of World Christian History, ed. Alison H. Howell. (Akropong: Akrofi Christaller Memorial Centre), 76-82.

19 Andrew F. Walls, The Cross-Cultural Process in Christian History: Studies in the Transmission and Appropriation of Faith. Maryknoll, New York: Orbis Books, 2005, p. 76.

20 de Nobili, "A Letter of Father Robert de Nobili to the Pope".

21 Ibid.

22 Kenneth Scott Latourette, A History of Christianity, 2, (New York: Harper \& Row, 1953).

23 Latourette, A History of Christianity

24 Rev. Fr. Donald Hinfey, SJ, Personal interview at the St Peter's Major Seminary, Pedu, Cape Coast, March 2007.
} 
before they are ordained as priests and they are later professed, based on one's individual record in his studies and his level of spirituality.

In terms of organization, the oral interview also revealed that a superior-general who lives in Rome heads the Jesuit. The superior general is elected to serve for life. Administratively, the Jesuits are divided into regions called provinces, vice provinces and mission territories. The superior-general appoints provincials and superiors to serve sixyear term.

\section{Methods used by the Jesuit (Rev. Fr. Roberto de Nobili)}

Rev. Fr. Roberto de Nobili was a member of the Jesuits (The Society of Jesus). In 1603, he was sent by the Pope to go to India to evangelize. After spending two years travelling, he arrived at Goa, and continued to Cochin and finally arrived at Madurai on $15^{\text {th }}$ November 1606 to begin a fifty-year career in the Jesuit Madurai Mission. ${ }^{25}$

When Fr. Roberto de Nobili went to Madurai, other Jesuits had been working there for (11) eleven years. However, he observed that all the people that his colleagues converted were either fishermen from the coast or Portuguese. Not even a single convert was a native of Madurai. Using his knowledge of inculturation theology, Fr. Roberto de Nobili decided to adopt certain measures and use certain methods that will enable him to do effective evangelism among the indigenous people.

The methods he used to propagate the gospel to win the Indians for Christ were radical identification, cultural transfer, indigenization, inculturation, and the use of their primal religion. These methods that were used by the Jesuit to fulfil his mission mandate are discussed in the following sections.

\section{(i) The Method of Radical Identification}

One of the methods used by the Jesuit to evangelize the people of Madurai in India was radical identification.The people practised the caste system so Fr. De Nobili decided that he had to identify with a particular caste before he could be totally accepted by the people. Looking at himself as someone with a royal birth from a royal Italian home, he decided to present himself as a Roman Raja. He therefore identified himself with the ruling class and joined the Kshatriyas caste. This made the people accept him to be one of them, and it paved the way for him to do a successful evangelism in the Madurai region of India. ${ }^{26}$

Later on, he had to identify himself with the Brahmins to become a sannyasi. This was to enable him to reach out to all manner of people, irrespective of their caste. The sannyasi was a caste for people of different classes who were highly respected by everyone in the Hindu society because they had renounced their lives and practiced a life of simplicity. Father Roberto de Nobili identified himself with them so as to make his interaction with them very cordial. He then used this opportunity to evangelise them and to convert them to Christianity. ${ }^{27}$ The Apostle Paul made use of this Radical Identification approach to mission to win souls for Christ. Paul said:

Though I am free and belonged to no man, I make myself a slave to everyone, to win as many as possible To the Jews I became like a Jew to win the Jews. To those under the law, I became like one under the law

.... I have become all things to all men so that by all possible means I might save some (1 Corinthians 9:19-22).

\section{(ii) The Method of Culture Transfer}

In the process of identifying himself with the people, Father Roberto de Nobili sought to transfer his culture. When he identified himself with the Indians, he began to imbibe their culture by dressing like a Hindu sannyasi, wearing wooden slippers, carrying a staff and a water jug like the way the Hindu's sannyasi who lead ascetic life present themselves. He built a little hut for himself and separated himself from the rest of the people in the community, including his fellow Christians. Jesuit Father Roberto de Nobili also abstained from eating meat and drinking alcoholic beverages. ${ }^{28}$

Through this method of cultural transfer, he presented himself to the Indians not as somebody with a different culture, but as somebody whose lifestyle was not completely different from their own. It was therefore not surprising that within the period of two years, he was able to convert about two hundred people to the Christian faith. ${ }^{29}$

\section{(iii) The Method of Inculturation}

Another method that was used by Father Roberto de Nobili was inculturation. Inculturation is the adaptation of the way Church teachings are presented to non-Christian cultures, so that the influence of those cultures will bring about religious transformation, which will ultimately affect the teachings of Christianity.

Father de Nobili did not hurriedly condemn the indigenous religion and culture of the people. Rather, he learned

\footnotetext{
25 de Nobili, "A Letter of Father Robert de Nobili to the Pope".

26 Ibid.

27 Ibid.

28 Ibid.

29 Ibid.
} 
to appreciate them and use them as basis for cultural transformation. For example, Father de Nobili did not force his converts to abandon their caste before they become true Christians. Converts were made to remain in their caste, keep their local names, and continue to use their local dialect.

Father de Nobili allowed his Christian converts to celebrate their local festival (the Pungal) with a difference. Instead of cooking their local food of rice and milk before an idol, they were to cook before a Cross, which was erected for that purpose. The Jesuit Father himself blessed the food before it was used for the ceremony. ${ }^{30}$ This method of inculturation allowed the Jesuit Priest to do a very effective evangelism among the people of Madurai in India.

\section{(iv) The Method of Indigenisation}

Indigenisation was another method that was used by the Jesuit to do effective evangelism in India in the $16^{\text {th }}$ and $17^{\text {th }}$ centuries. The study of the indigenous language was used for the purpose of evangelization. To enable him to reach out to the people, there was the need for him to study the local language of the people. When he became a sannyasi, he was expected to study hard in order to teach others the ways to the truth. His desire to study the Hindu religion made him learn the Tamil language, and he became an expert in the use of the language. It has been documented that Father de Nobili could speak the Tamil language so well that his diction could not match that of the Brahmin scholars. His good mastery of the language enabled him to study the works of most famous poets who were held in high esteem among the Madurai. Besides, Father de Nobili was able to learn most of their hymns, and could sing them by heart with perfection, to the admiration of all. ${ }^{31}$

The Jesuit also learnt the Sanskrit language. He found a scholar who volunteered to teach him how to read the Vedas (i.e., the Hindu Scriptures) in the Sanskrit language. The study of the Hindu scriptures enabled him to understand the basic foundation of Hinduism (i.e., the indigenous religion), and to use it as a tool for teaching the gospel to the indigenous people. Learning the language enabled him to communicate effectively with the Hindus. This made their conversion to Christianity very easy for the Jesuit. ${ }^{32}$

\section{(v) The Use of Primal Religion}

Another evangelistic strategy that was used by Fr. Roberto de Nobili was the use of primal religion of the Indians. The word "primal" means something which is "primitive" or "basic". A primal religion is a religion that is practised by an indigenous people within their indigenous culture. Theologians like William Robertson Smith $^{33}$ and Gillian Mary Bediako $^{34}$ have contributed to the study of primal religions. Adherents of primal religions believe that spirits dwell in certain inanimate objects within the cultural environment, ranging from animals to the land on which they live. Primal religions are usually pre-scientific, and they rely on myths and rituals, rather than written code of ethics to regulate the conduct of their members. Edward E. Evans-Pritchard, a British Professor of Social Anthropology at the Oxford University has examined the various theories which have been put forward by anthropologists to explain the origin of religions of primitive people..$^{35}$

Fr. Roberto de Nobili used his knowledge of primal religion to propagate the Christian gospel among the Indians. As a result, he urged the people not to destroy the temples of the idols of the Indians. He rather advised that the temples should be converted from the worship of idols to the worship of the true God. According to him, since the people would be more familiar with their places of worship, it would put them in a better position to worship the true God.

Father de Nobili also suggested that since people were familiar with the slaughtering of animals to their deities, they should be encouraged to slaughter cattle and praise God while eating them. According to him, these methods should be put in place because "it will be impossible to efface everything at once from their obdurate minds" ${ }^{36}$

\section{An Appraisal of Mission Methods in Africa}

Christianity was introduced in Africa from Europe through the efforts of Christian missionaries. In Ghana, some of the European missionaries who helped to spread Christianity were the Basel Mission, the Catholic Mission, the Wesleyan Mission, and the Bremen Mission. Christianity was presented in European culture and as a result, its encounter with the African culture attracted different kinds of responses.

According to Ukpong Justin, a Nigerian theologian, Africans responded to Christianity, which was presented to them with European culture dominating in four main ways: first, by totally rejecting western Christianity, leading to

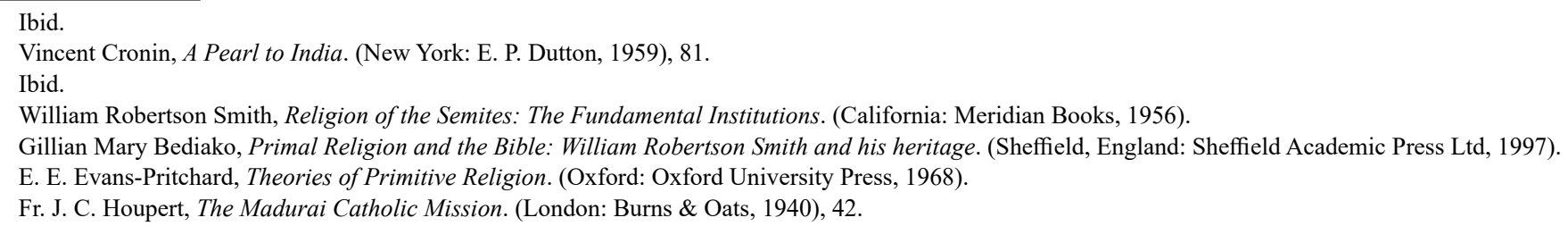


the introduction of a new religion (e.g. Afrikania); second, by replacing western Christianity with African Christianity; third, by practising western Christianity alongside indigenous religion (i.e., syncretism); and four, by transforming western religion from within to give it African identity, using the method of "Inculturation". ${ }^{37}$

The term "Inculturation" is defined as "a two-way process of interaction between the Christian faith and a culture that effects a transformation of the culture and a re-interpretation of faith.$^{38}$ Inculturation, as applied to Christianity, must be understood to be a process of transformation of (Christian) religious culture, leading to a reinterpretation of the Christian faith. Inculturation is the adaptation of Christian teachings in a non-Christian cultural environment (e.g. within an African traditional religious setting), for the purpose of saving souls and transforming society.

Inculturation theology is a subject that has been explored extensively by a number of theologians in Africa. These include Justin Ukpong, ${ }^{39}$ Laurenti Magesa, ${ }^{40}$ Aylward Shorter, ${ }^{41}$ Andrew Orta,,${ }^{42}$ and Charles Nyamiti. ${ }^{43}$ In Ghana, some theologians who have contributed to the study of the subject of Inculturation theology were Kwame Bediako, ${ }^{44}$ John Samuel Pobee, ${ }^{45}$ Emmanuel Martey, ${ }^{46}$ Mercy Oduyoye, ${ }^{47}$ and Kofi Appiah Kubi. ${ }^{48}$ It is of interest to note that though a number of Ghanaian theologians have contributed to the study of theological education in Africa ${ }^{49}$ not much have been done about the subject of theological education in Asia by Africans in general, and Ghanaians in particular..$^{50}$ This study has been used to fill in the research gap by studying the subject of inculturation theology in a Christian Church in India, Asia, from an African perspective. The study also seeks to examine the implication of Jesuit Christianity in India in the $16^{\text {th }}$ and $17^{\text {th }}$ centuries for Christian mission in Ghana in the $21^{\text {st }}$ century.

Using the Inductive method, four theories have been developed from Justin Ukpong's "inculturation theology". Where the people totally rejected the culture, the author has referred to that response as the "cultural rejection approach to mission". Where the people rejected the western culture by replacing it with African form of Christianity (AIC), the author has referred to that response as "cultural replacement approach to mission". Where the people practised "syncretism", the author has referred to that response as the "cultural sharing approach to mission". Finally, where the people accepted the western religious culture and tried to transformed it to suit their African identity using inculturation, the author has referred to that mode of response as the "cultural transformation approach to mission". Thus the "cultural transformation approach to mission" is what fits into Justin Ukpong's concept of "inculturation theology", and this provides a theoretical framework for this study.

The "cultural transformation approach" to mission requires that people accept western Christianity and try to transform it to suit their indigenous culture, in order to preserve the identity of the indigenous people. It was this "cultural transformation approach to mission" that was used by the Italian Jesuit to establish Christianity in India in the $16^{\text {th }}$ and $17^{\text {th }}$ centuries. The Jesuit used this theological approach to fulfil the mission mandate, and it led to the success of the work of mission that was done among the Indians.

Noel Smith described how the inculturation theology, which I now refer to as "cultural transformation approach to mission" influenced the Basel Mission to fulfil its mission mandate in the Gold Coast in $1828 .{ }^{51}$ According to him, the first batch of the Basel Missionaries who were sent to the Gold Coast in 1828 were given the following instructions to follow:

Firstly, they were to adapt themselves to the climate; secondly, they were to take time to select a site for a permanent mission station; thirdly, they were to master the local language at all costs; finally, they were to present the gospel with love and patience. In this way, ... they would be able to heal the bleeding wounds, which 'greed of gain and the cruel craftiness of the European have caused'. ${ }^{52}$

\footnotetext{
Justin Ukpong. "Inculturation Theology in Africa: Historical and Hermeneutical Developments", in Handbook of Theological Education in Africa, (London: Regnum Books International, 2013), 530.

Ibid., 531.

Justin Ukpong. "Towards a Renewed Approach to Inculturation Theology”. Journal of Inculturation Theology. 1, no 1 (1994), 3-24.

Laurenti Magesa Anatomy of Inculturation: Transforming the Church in Africa. (New York: Orbis Books, 2014).

Aylward Shorter. Toward a Theology of Inculturation. (New York: Orbis Books, 1988).

42 Andrew Orta. Inculturation Theology and the "New Evangelization", ed. Virginia Gerrard-Burnett, Paul Freston, and Stephen C. Dove. (Cambridge: Cambridge University Press, 2016).

43 Charles Nyamiti. Christ as our Ancestor. (Gweru: Mambo Press, 1984).

44 Kwame Bediako. Jesus in Africa. (Akropong-Akwapim: Regnum Africa Books, 2001).

45 John Samuel Pobee. Toward an African Theology. (Nashville: Abingdon, 1979).

6 Emmanuel Martey, African Theology: Inculturation and Liberation. (Maryknoll: Orbis Books, 1993).

47 Mercy Oduyoye and R. A. Kanyoro Musimbi. The Will to Arise: Women Tradition and the Church in Africa. (Maryknoll: Orbis Books, 1992).

48 Kofi Appiah Kubi and Sergio Torres (ed.). African Theology en Route: Papers from the Pan-African Conference of Third World Theologians, (December 17-23). (Accra / Maryknoll: Orbis Books, 1977).

49 Handbook of Theological Education in Africa, edited by Isabel Apawo Phiri and Dietrich Werner. (Oxford: Oxford Centre for Mission Studies, 2013).

50 The Association for Theological Education in South East Asia (ATESEA) Handbook. (Philippines: Association for Theological Education in South East Asia, 2014).

51 Rev. Dr. Noel Smith was a Basel Missionary and a former Principal of the Presbyterian Training College at Akropong-Akuapem, Ghana.

52 Noel Smith, The Presbyterian Church of Ghana, 1835-1960, (Accra: Ghana Universities Press, 1966), 28-29.
} 
Thus, knowledge of inculturation theology helped the Basel Mission to succeed in its efforts to establish the Basel Mission Church which has now become the Presbyterian Church of Ghana.

\section{Lessons for the Church in Ghana in the $21^{\text {st }}$ Century}

Churches in Ghana can draw lessons from Jesuit Christianity in India in the $16^{\text {th }}$ and $17^{\text {th }}$ centuries by considering the motives of mission, and the use of "cultural transformation approach" to Mission.

First, the Jesuit believed that mission should be "cross-cultural". He believed that language, which is a component of culture, should not be a barrier to the spread of the gospel. For this reason, he studied the indigenous language of the people (the Tamil language) and used it to communicate the gospel to the Indians. The Christian Church in Ghana in the $21^{\text {st }}$ century is therefore encouraged to use the indigenous language of the people as a means to communicate the gospel to them. The Basel Missionaries had a theology of language, which was based on the presupposition that the gospel should be incarnated in the vernacular. ${ }^{53}$ As a result, J. G. Christaller helped to develop the Twi language, while Zimmerman helped to develop the Ga language. The use of the local languages therefore became a major feature of Basel Mission language policy in the Gold Coast. ${ }^{54}$ Fulfilling the mission of the Church in Ghana in the $21^{\text {st }}$ century requires this kind of approach to mission.

Secondly, the Jesuit believed that mission should be "international". Its international nature compelled the Italian Jesuit to move from Italy (in Europe) to India (in Asia) to embark on mission. This motive has its theological basis in Genesis 12:1 where Abraham was asked by God to leave his country, his people and his household from Ur of the Chaldeans and go to Haran, in order to fulfil his mission mandate. The Basel Mission followed this example by recruiting missionaries from different European countries and sending them to the Gold Coast in the 1800's to evangelize. Initially, missionaries were recruited from South-West Germany (mainly Lutheran) and Switzerland (Reformed). ${ }^{55}$ Similarly, in 1831, among the three Basel missionaries who came to the Gold Coast, two were from Denmark (Andreas Riis and Peter Petersen Jaeger), and one was from Saxony (Christian Frederich Heinze). ${ }^{56}$ It is therefore not surprising that many of the Charismatic Churches that are established these days add "International" to their names, so we can hear of "Cross Fire International Ministry", "Jesus Generation International Ministry", and many others. Meanwhile their activities are just limited to Ghana. $21^{\text {st }}$ century Christians should be ready to take the Gospel beyond borders.

Thirdly, mission must be understood to be "holistic" in nature. The Jesuit believed that the gospel should be used as an instrument to bring transformation in the lives of the people of India. He was interested in providing not only the spiritual needs of members but he also provided their cultural needs. It was for this reason that Father de Nobili decided to allow his converts to remain in their caste, keep their local names, and continue to use their local dialect while they remained Christians. The Basel Mission for example understood mission to be holistic. Peter Wagner quoted John Calvin as teaching that all believers have a dual mandate to fulfil - a cultural mandate to transform society, and an evangelistic mandate to save souls. ${ }^{57}$ This contributed to the success of the Basel Mission, as it invested in education, agriculture, health and infrastructure for the benefit of humanity. $21^{\text {st }}$ century Christian Churches in Ghana can learn from the India experience and use the gospel to address the spiritual, social, emotional and material needs of members.

Fourthly, mission was understood to be "co-operative" in nature. The "co-operative" nature of mission encouraged Rev. Fr. Roberto de Nobili to join the Jesuits Order (Society of Jesus). Besides, before he was sent to Madurai, other Jesuits had already been sent to work there for eleven years, and they had converted some fishermen and Portuguese. Fr. De Nobili believed that mission should be holistic and for that matter, the natives should also be converted. He therefore managed to covert some of the natives of Madurai in India. Besides, the "co-operative" nature of mission encouraged Jesuits to engage in evangelism and make converts in fulfilment of mission in India. The Basel Mission for example had this kind of "co-operative" attitude towards mission. This attitude guided the formation of the Basel Mission Society, which recruited and sent missionaries to the Gold Coast to do the work of mission. The implication of the co-operative nature of mission is that Christian Churches in Ghana in the $21^{\text {st }}$ century should be encouraged to join local ecumenical bodies like the Christian Council of Ghana, the Ghana Pentecostal Council, as well as international bodies like the World Council of Churches, for the purpose of coordinating and promoting the work of mission.

Fulfilling the mission of the Church in Ghana in the $21^{\text {st }}$ century requires that the church must develop appropriate skills and methods required for the work of mission. The Italian Jesuit used "radical identification", "culture transfer", "indigenization", "inculturation" and "primal religion" as evangelistic methods to fulfil the mission mandate. This resulted in the success of mission in India.

\footnotetext{
53 Cephas N. Omenyo, Pentecost Outside Pentecostalism: A Study of the Development of Charismatic Renewal in the Mainline Churches in Ghana. The Netherlands: Boekencentrum Publishing House, 2006, p.54.

54 Ulrike Sill, Encounters in Quest of Christian Womanhood: The Basel Mission in Pre-and Early Colonial Ghana. Leiden: Brill, 2010. p.104.

55 Omenyo, Pentecost Outside Pentecostalism, 52.

56 Smith, The Presbyterian Church of Ghana, 1835-1960.

57 Peter C. Wagner, The Church in the Workplace. (Ventura: Regal, 2006), 36.
} 
The "radical identification" approach will require that churches in Ghana should use the church groups like singing groups and day-born groups to help bridge the gap between the rich and the poor in society. This approach will help people to identify themselves with social group, irrespective of their age, social status or educational background. The "culture transfer" approach for doing mission requires that people identify with others within social groups in society by imbibing their culture through the wearing of their clothes and learning to speak the indigenous language of the host community. The use of "radical identification" and "culture transfer" will help the church to achieve the United Nations Sustainable Development Goal (UN SDG) 10, which seeks to reduce inequality in society.

The "indigenization" approach to mission requires that the mother tongue should be used by the Church in Ghana for doing mission in the $21^{\text {st }}$ century. "Indigenization" will help members of the Church to study the indigenous language of the people, for the purpose of reading to understand the Bible and using it for evangelism and for spiritual growth. The "inculturation" approach requires the adaptation of the way Biblical teachings are presented to people within non-Christian cultures, so that the influence of those cultures will bring about religious transformation without condemning the indigenous culture or forcing converts to repudiate their culture. Knowledge of "primal religion" will provide a basis for the propagation of the gospel. The use of "indigenization", "inculturation" and "primal religion" will help the Church to achieve the United Nations Sustainable Development Goal (UN SDG) 4, which seeks to provide quality education in society.

\section{CONCLUSION}

The study has examined how Christianity was established in India in the $16^{\text {th }}$ and $17^{\text {th }}$ centuries and the lessons that could be drawn from the Jesuit experiences, in fulfilment of the mission of the church in Ghana in the $21^{\text {st }}$ century. The research findings revealed that Jesuit Christianity was introduced in India in the $16^{\text {th }}$ and $17^{\text {th }}$ centuries to save people from poverty, ignorance and hardship, in fulfilment of the purpose of mission, which was defined in terms of liberation. The Jesuit understood the motives of mission to be cross-cultural, international, co-operative and holistic. Four theories were developed from Justin Ukpong's "inculturation" theory, namely: "cultural rejection approach", "cultural replacement approach","cultural sharing approach" and "cultural transformation approach" to mission.

The study revealed that the Jesuit used the "cultural transformation approach" to mission, which required the use of "radical identification", culture transfer", "indigenization", "inculturation" and "primal religion" as evangelistic methods for mission. It is therefore recommended that in the $21^{\text {st }}$ century, churches in Ghana should adapt the "Cultural Transformation Approach" to mission, with the hope that using strategies like the Radical Identification and Culture Transfer approaches to mission will help to reduce inequality in society, in fulfilment of UN SDG 10; while knowledge of the use of Indigenization, Inculturation and Primal Religion will provide inclusive and equitable quality (theological) education and promote lifelong learning, in fulfilment of UN SDG 4.

\section{BIBLIOGRAPHY}

Appiah Kubi, K. and Torres, S. (ed.). African Theology en Route: Papers from the Pan-African Conference of Third World Theologians, December 17-23, 1977. Accra / Maryknoll: Orbis Books.

Bediako, G. M., Primal Religion and the Bible: William Robertson Smith and his heritage. Sheffield, England: Sheffield Academic Press Ltd, 1997.

Bediako, K., Jesus in Africa. Akropong-Akwapim: Regnum Africa Books, 2001.

Bosch, D., Transforming Mission. New York: Orbis Books, 1991.

Cairns, E. E., Christianity through the centuries. Grand Rapids: Zondervan, 1996.

Cronin, Vincent, A Pearl to India. New York: E. P. Dutton, 1959.

de Nobili, Robert, "A Letter of Father Robert de Nobili to the Pope", in Indian Church History Review, 1, no. 2, (1968), 84-96, in Aspects of World Christian History, compiled by Alison H. Howell. Akropong: Akrofi Christaller Memorial Centre, 76-82.

Evans-Pritchard, E. E., Theories of Primitive Religion. Oxford: Oxford University Press, 1968.

Google. "Padroado", https//www.britannica.com>event Accessed October 20, 2018).

Houpert, J. C, The Madurai Catholic Mission. London: Burns \& Oats, 1940.

Hrangkhuma, J. C., The Church in India, in Church in Asia Today, edited by Saphir Athyal. Singapore: Lousanne Committee for World Evangelization, 1996: 393-400.

Hubert, T. C., World Missions Today. Wheaton, Illinois: Evangelical Teacher Training Association, 1981.

Idowu, E. B., Towards an Indigenous Church. London: Oxford University Press, 1965.

India Country Profile (2020) https://www.bbc.com Accessed February 18, 2020).

Kpobi, D. N. A. Mission in Ghana: The Ecumenical Heritage. Accra: Asempa Publishers, 2008.

Latourette, K. S., A History of Christianity, Vol. 2, New York: Harper \& Row, 1953.

Magesa, L., Anatomy of Inculturation: Transforming the Church in Africa. New York: Orbis Books, 2014. 
Martey, E, African Theology: Inculturation and Liberation. Maryknoll: Orbis Books, 1993.

Nyamiti, C., Christ as Or Ancestor. Gweru: Mambo Press, 1984.

Oduyoye, M. and Kanyoro, M. R. A., The Will to Arise: Women Tradition and the Church in Africa. Maryknoll: Orbis Books, 1992.

Omenyo, C. N., Pentecost Outside Pentecostalism: A Study of the Development of Charismatic Renewal in the Mainline Churches in Ghana. The Netherlands: Boekencentrum Publishing House, 2006.

Orta, A., Inculturation Theology and the "New Evangelization". Edited by Virginia Gerrard-Burnett, Paul Freston, and Stephen C. Dove. Cambridge: Cambridge University Press, 2016.

Pero, A. P., A view of Lutheran Unity from a Black Perspective, in Dialogue, 20, (1981).

Phiri, I. A. and Werner, D., ed., Handbook of Theological Education in Africa. Oxford: Oxford Centre for Mission Studies, 2013.

Pobee, J. S., Toward an African Theology. Nashville: Abingdon, 1979.

Shekhar, K., "The Concept of the Church in Christianity". Imperial Journal of Interdisciplinary Research (IJIR), 3, no. 2, (2017). http://www.onlinejournal.in

Shorter, A., Toward a Theology of Inculturation. New York: Orbis Books, 1988.

Sill, U., Encounters in Quest of Christian Womanhood: The Basel Mission in Pre- and Early Colonial Ghana. Leiden: Brill, 2010.

Smith, N., The Presbyterian Church of Ghana, 1835-1960: A Younger Church in a Changing Society. Accra: Ghana Universities Press, 1966.

Smith, W. R., Religion of the Semites: The Fundamental Institutions. California: Meridian Books, 1956.

Stephen, N. A, Gerald, H. \& Goodwin, John, (eds.) A Concise Dictionary of the World Mission. London: Lutterworth Press, 1971.

The Association for Theological Education in South East Asia (ATESEA) Handbook. Philippines: Association for Theological Education in South East Asia, 2014.

Ukpong, J., "Inculturation Theology in Africa: Historical and Hermeneutical Developments", in Handbook of Theological Education in Africa, London: Regnum Books International, 2013, 530-542.

Ukpong, J., Towards a Renewed Approach to Inculturation Theology. Journal of Inculturation Theology. 1, no. 1 (1994), 3-24.

Wagner, P. C., The Church in the Workplace. Ventura: Regal, 2006.

Walls, A. F., The Cross-Cultural Process in Christian History: Studies in the Transmission and Appropriation of Faith. Maryknoll, New York: Orbis Books, 2005.

\section{AUTHOR BIODATA}

Seth Asare-Danso (PhD) is an Associate Professor, Head of Department - Arts Education, Vice Dean and Protestant Chaplain of University of Cape Coast. His research interests are in the areas of Curriculum, Pedagogical and Historical issues in Religion; Educational Management and Policy issues; and Theological Education. 